\title{
Actualization of Separatist Ideology in Aceh Post Peace Agreement through on Social Media
}

\author{
Rusli Yusuf*, Maimun \\ Civic Education Department, Teacher Training and Education Faculty \\ Syiah Kuala University \\ Aceh, Indonesia \\ *rusliyusuft@unsyiah.ac.id
}

\begin{abstract}
This study aims to analyze socialization of separatist symbol post peace agreement as the struggle form of GAM ideology which is done through media social. This study is categorized as type of descriptive study with qualitative approach and by using analysis toward social media by delving out information from subject chosen in purposive, namely subject which is determined based in special consideration, and the numbers of media social account studied are 20 accounts for 2016 until 2017.In addition, this study use semiotics analysis to analyze socialization of GAM ideology through symbol which refer to semiotic theory proposed by Charles Sanders Peirce (1839-1914) which offer triadic model and its trichotomy concept which are divided into three things, namely: sign, interpretant, and object. From the result of study it is found that: GAM symbols which are socialized through media social of post peace agreement among others are: (1) the symbols which consist of: Buraq-lion, Star and Yellow Crescent, blue-yellow and black flag, renchong, and Arabic-malay writing, (2) Flag; four white lines, star and white crescent, and two black lines which each lie in the middle of white line. Information about the symbol of GAM mostly uploaded through facebook with $60 \%$ information about the symbol of The Free Aceh Movement, 5\% in twitter and 15\% in WhatsApp and $20 \%$ in Youtube and information from youtube also is shared again via facebook. Based on this study, it can be concluded that socialization of GAM symbol through media social of post peace as a form of struggle toward separatist ideology of The Free Aceh Movement which is still done until one decade of peace agreement. If this socialization is continuously done then it will potentially make Aceh return to conflict cycle of post peace agreement 10 - 15 years ago.
\end{abstract}

Keywords-social media; socialization; symbol of GAM

\section{INTRODUCTION}

As for according to data collected by international nonGovernmental Organization (NGO) headquartered in London, England that there are 3000 peoples killed, 3,862 peoples missing, 4,663peoples are tortured, 186 women are raped, 16 thousands children lose their parents and 90 Thousands people escape and become homeless. It is as mentioned in the report of [1-3]. From some researcher' notes above, it can be known that conflict in Aceh had caused Aceh regression in almost all life sectors such as economy, education, infrastructure, law, social and culture and also regression in mental and spiritual aspects. The opportunity which can be used to rebuild Aceh post conflict and tsunami is the allocation of special autonomy grant which achieve 100 billions for the term of 20 years (20072038), which the detail for 15 years (2007-2022) of outsurgain in Aceh is equal with $2 \%$ of national General Allocation Grant, and 5 years after that (2022-2027) obtain 1\% which is equal with National General Allocation Grant. In addition of special authority grant, Aceh also obtain the grant from oil and gas profit sharing which achieve $75 \%$.It is in accord with the report of $[1,3-5]$. The special autonomy grant provided for Aceh is intended to rebuild Aceh which had been left behind for long time as result of conflict and also the destruction as result of earthquake and tsunami. Therefore, the priority of Aceh special authority is prioritized to six (6) main sectors, namely infrastructure building and maintenance, people economic empowerment, poverty eradication, and educational, social and health funding. According to Galtung, that "positive and negative peace always give effect to a condition in a region [6]. The meaning of positive peace is the achievement of entry point from peace agreement result, whereas negative peace is peace agreement achievement can not be realized by the parties who want peace. In the other word, negative agreement is an arid climate which cannot realize a justice condition, economical equality and access to education for the people who are effected by conflict post peace" [1-5]. Hence, a conclusion can be drawn that Aceh peace is categorized into negative peace which means that post peace, justice values and the equality in access to economic, education, social and culture, politic and law still far for expectation. It can potentially bring Aceh back into conflict situation as ever experienced by another countries in the world.

The socialization of symbols and emblems of GAM separatist is done by agents through some approaches, among others by media social approach. So, in this modern era, the agents who are affiliated with Aceh separatist ideology are continuously try to give influence to social media users in Aceh. The socialization of separatist symbol and emblem is increasingly easier to be done by the separatism agents of GAM, even in digital era, social media such as Facebook, twitter, Line, YouTube, Whatsapp, etc. are media which have attraction for most Indonesian people, including in Aceh. The high rate of social media users in Aceh make easier for the agents to socialize the values contained in the symbols of GAM separatist. This network show the way where they can connect because of the common in sociality, started from the acquaintances until family [7]. In the report released by Tetra 
Pak Index in 2017, there are about 132 millions of internet users in Indonesia. Meanwhile, almost a half of them are social media freak, or around the figure of $40 \%$. This figure is increase compared to last year. In 2016 the increase of internet users in Indonesia is around 51\% or around 45 millions of user, followed by the growth of active social media users around $34 \%$. Whereas, the users who access media social through mobile phone is $39 \%$. Tetra Pax Index also reveal that more than 106 millions of Indonesian people use social media each month with $85 \%$ who access media social through cellular phone. It means that media social users in Indonesia is in 4th rank in the world after US, India and Brazil. The data about the profile of internet users in Indonesia show that category of the most media social user is Facebook, that is, $65 \%$, then in the second rank is Twitter with $20 \%$, as seen in the figure 2 below. There is higher number of users in Aceh compared with some another provinces in Indonesia. For example, in Banda Aceh the internet user achieve 244.000 people, which is higher than the users in Medan City.

In some reports of researcher conducted earlier, it can be drawn a conclusion that symbols give certain message and meaning to audience or reader, or people who see it. One research conducted Piliang showed that "the symbols of GAM had gave big influence to the emergence of new sympathizer and fanatic for the persons who see it [8]. In addition, according to Piliang, the symbols of GAM separatist also had capable to raise the spirit of GAM separatist agents to fight for their ideology in fighting the authorized government. In addition, symbol also represent the existence of power of separatist group, so the socialization of symbols and flag of GAM since 1976 is one of approach models used by separatist GAM to build the power by increasing the numbers of The Free Aceh Movement Army personnel. At that time, the socialization of separatist symbol will be more easily done by the agents, but it is because the social media users in Aceh not only in Banda Aceh, but almost distributed equally in all villages existed in Aceh. It is because the internet which is easier to be accessed only by using Handphone Android and cheap internet service from the internet service provider such as 3, Simpati and Smartfren, etc. Based on the background explained above, an assumption is proposed that "the socialization of GAM symbol which is done through media social will give effect to development of fanatic attitude toward The Free Aceh Movement ideology. If the socialization of symbols is continuously done.

Study aims to analyze the socialization of symbols and GAM separatist symbol of post peace agreement as the struggle form of GAM ideology which can be done through Social media.

\section{THEORETICAL BASE}

\section{A. Semiotic Theory}

The study on symbol had been conducted before, and this study is categorized into family of semiotics science. Semiotic is one branch of linguistic which is in meaning level. In this case, Verhaar say that semantic is the theory about meaning. The word semantic is agreed as the term used for linguistic field which study the relation between linguistic sign and the signified. However, the use of symbol theory in this study do not change substance and aim which want to be achieved in this study, namely describing the phenomena of socialization of separatist symbol post peace agreement as the realization of struggle of The Free Aceh Movement ideology.

Semiotic as a model of social science understand the world as the system of relation which has basic unit called as "sign". Therefore, semiotic study the essence of existence of a sign. Semiotic is science which study a sign. In communication science, "sign" is a meaning interaction delivered to another people through signs. Communication not only done in spoken words but also by using that sign. The existence or nonexistence of an event or structure which are found in something, a habituation, all of these can be called as sign. A flag, a hand gesture, a word, a silent, a nerve motion, the event that face become red, hair become gray, the gaze of eye and many other things are considered as a sign Wibowo. Then according to Eco, sign will always refer to another thing (object) called as referent. The red lamp refer to the road which is stopped, the reddish face refer to shyness or happiness, tears refer to sadness. If there is relation between the sign and referent, then understanding will emerge in the mind of people who see or hear it [9].

The theoretical base in this study adopt semiotic theory proposed by Charles Sanders Peirce namely there are three important aspects called as the triangle of meaning [10]. Those three aspects are: first, sign. In semiotic study, a sign is main concept which is made to become analysis material in which a sign contain meaning as the form of interpretation for the intended message. Simply, a sign tend to has visual and physical form captured by human. Second, sign or object. Object is social context which in its implementation is made to become meaning making aspect or which is refereed by that sign. Third, interpretant. The concept of thinking which use sign and give it a certain meaning or existing meaning in one's mind about the object which is refereed by a sign.

The concept of semiotics according to Charles S. Peirce in James that "all the ways of thinking depend on the use of signs" [10]. Peirce argue that each thinking is sign, and that each reasoning action consist of sign interpretation. Human only think in sign. Human communicate in sign to understand and think about the world. According to Peirce, to understand a sign, first that sign should be observer in order to know the function of that sign. A sign should be captured, representative, and interpretative.

By referring to Charles Sanders Peirce in James, the pragmatist see a sign as "something represent something" [10]. The interesting is that "something" can be a concrete thing (can be captured by human five senses), which then through process, represent "something" exist in human cognition. Thus, what is seen by Peirce, sign is not a structure, but a cognitive process derived from a "representation" is called as repersetamen (ground), whereas "something" exist in cognition is called as object. The process of relation from repersentamen to object is called as semiosis. In making meaning of assign, this semiosis process had not been completed because there is one continued process called as interpretant (interpretation process).Thus, in outline, the making meaning of sign operated 
in semiosis process from concrete to human cognition who live in social life.

Peirce divide the signs in drawing and it can be seen from the type of sign which is categorized in semiotics. Among others are icon, index and symbol. First, by following the nature of its object, when we call sign as icon. Second, it become reality and its existence relate to individual object, when we call a sign as index. Third, it is interpreted as denotative object as a cause of a habituation when we mention a sign as Icon as sign whose relation between the signifier and the signified is in natural form. In the other word, icon is relation between sign and object or reference which is resemblance. Index is a sign which show that there is natural relation between sign and signified which is causal or causal effect relation, or sigh which refer directly to reality. And symbol is sign showing natural relation between signifier and it's signified. This relation is arbitrary, this relation based on convention among society.

Finally, Peirce convince that human think in sign so he create sign science which is called as semiotics. Semiotics for them is synonym with logic. Literally, he say that "We only think in sign". Besides, he also see a sign as element in communication. He increasingly convince that everything is sign. In his semiotic analysis, Peirce in James divide sign based on the property of ground into three groups namely qualisigns, sinsigns and legisigns [10].

First, Qualisigns are signs which are based on their property. For example, the red property is qualisgins because it is sign in possible field. Second, Sinsigns is sign which is sign based on its performance in reality. All individual statements which are not institutionalized are Sinsigns. A scream can be pain, wonder or joyful. Third, Legisigns are signs which are based on a rule, a convention or a code which are generally applied. The traffic signs are legisigns. Similarly with nodding a head, shaking a hand, etc. For sign and its denotatum, Peirce focus himself in three aspects of sign namely iconic, indexical, and symbol. Iconic is something which function as signifier which is similar with the form of its object (seen in picture or painting).Index is something which function as signifier which imply its signified, whereas symbol is signifier which function as signifier based on conventional rule had been generally used in society.

\section{METHOD}

This study will describe the phenomena of socialization of separatist symbol as the form of struggle of GAM ideology post peace. The process of data collection is done by studying media social account with total of 20 accounts. According to Moleong that "data collection technique is the way used to collect information or facts in field [11]. Data collection technique is the most important step in study, because the main aim of study is to obtain data. In addition analyzing 20 contents in those media social accounts, data collection also done by doing communication through electronic mail (email, chatting and Whatsapp) with those account owner. It is done to ask additional information from those media social owner. Data analysis in this study is done immediately after the data collected so researcher is avoided from misinterpretation.
Reveal that activity in qualitative data analysis is done interactively and continuously until finished, so the data has been saturated. Activities in data analysis are data reduction, data display, and conclusion drawing/verification.

\section{RESULT AND DISCUSSION}

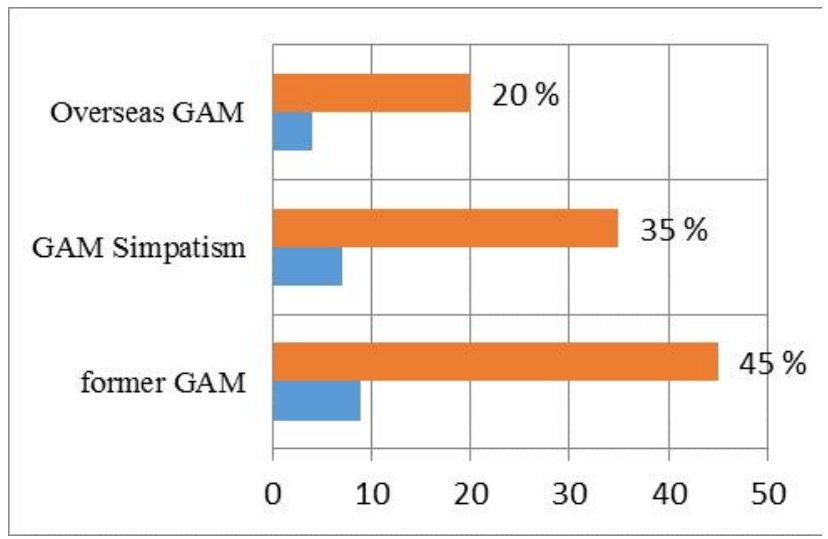

Fig. 1. Owners of social media accounts.

The following study result is based on analysis of material about Separatist symbols of The Free Aceh Movement or GAM contained in media social account for two years, namely since 2016-2017. On the figure 1; Media social account which is analyzed for this study are 20 accounts which are divided into three groups: first, 9 media social accounts owned by GAM combatants who are now staying in Indonesia. Second, 7 media social accounts owned by GAM sympathizer/supporters who are now staying in Indonesia but outside Aceh. Third, 4 media social accounts owned by GAM civil who are now staying abroad such as in Malaysia, Australia and Europe. Besides, from 20 accounts studied, the account owners who are most dominant updating status about GAM symbol are GAM civil who are now staying abroad by using facebook as media social.

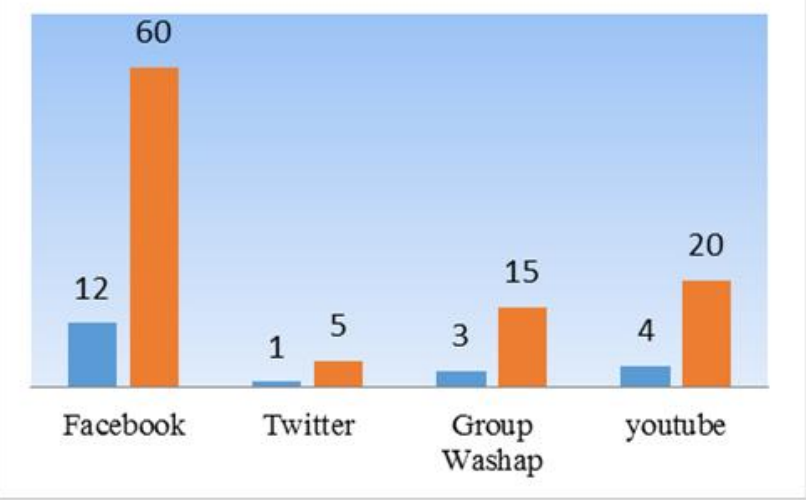

Fig. 2. Social media accounts containing GAM symbols.

On the figure 2; As known that information about GAM symbols is mostly uploaded via facebook, that is $60 \%$, whereas information about GAM symbols which is updated through twitter only $5 \%$, and information update by using Youtube is $20 \%$ which also shared again via facebook as seen in figure 2 
below. Based on that figure, it can be known that until now facebook still become the most reliable media social for user for promotion, socialization, news even to deliver hoax. Facebook is categorized as type of media social which is easily accessed because facebook features had been designed as sophisticated as possible, so each time the status is updated by the user, it will delivered to another users in network cycle. It can make a news to spread faster via facebook, whether it is true or hoax.

The next study finding is related to flag and symbols of The Free Aceh Movement or GAM which is contained in wall of media social owner, so this category is included in socialization done purposely. Based on analysis result obtained from interview with the owners of media social account, the result is found that post peace agreement, there is no more socialization activity of GAM which is done overtly in front of public, such as political speech, mass mobilization to promote GAM ideology as ever done by GAM organization before the peace achieved. Actually, not all elements contained in the body of GAM agreed to hold Helsinki agreement. For some parts of GAM element, particularly they who live abroad desire Aceh as sovereign country and they do not want peace. For them, Helsinki peace only Indonesian government's tactic to conquer again Aceh and become integral part of Unitary State of Republic of Indonesia. Not only GAM elements who are now staying abroad, but another elements namely ex-combatant of GAM who are now living in Aceh and even they are Tripoly alumni, and ex-combatant of GAM who had ever been jailed in Nusa Kambangan. So until 12 years after peace agreement, they still wish that in the future Aceh will become sovereign country, even though only struggling pattern which is shifted. Before peace agreement, the struggle to seize independence is done by weapon, whereas post peace agreement, the struggle of Aceh independence is done through political path, so they want Aceh Party (local political party) can continue the struggle of Aceh ideology which ever done by Ha san Tiro et al in the past.

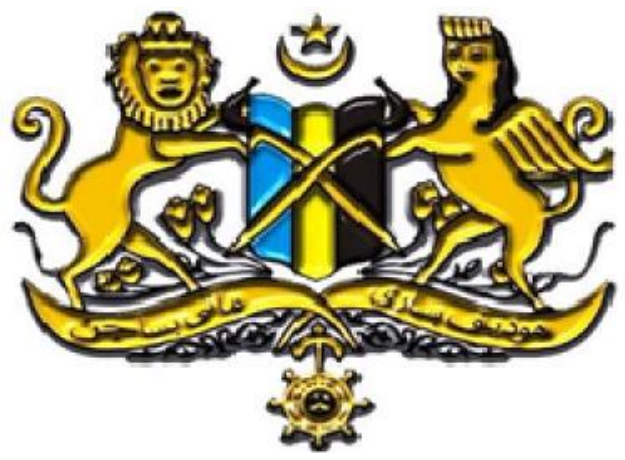

Fig. 3. Aceh free movement symbol.

As for the symbol which is often contained in the wall of media social owner is The Free Aceh Movement or GAM symbol as seen in figure 3 below. The symbol is well known as Buraq Lion. In that symbol, there are five parts of symbol in it, and each has its own meaning from each symbol, namely: First, The lion crowned which is symbol of sovereignty of the State of Aceh). It means that Aceh is sovereign and independent country in Sumatera Island, has territorial, people, has head of State and constitution, and apply "Adat bak Po Teumeureuhom"Second, Buraq is animal who run as fast as lighting in Islam mythology. Buraq here means the light. In Islam mythology, buraq means a vehicle ridden by The Prophet Muhammad SAW during Isra' and Mi'raj (The Travelling from Masjidil Haram to Masjidil Aqsa in Jerusalem, and from there arrived to Sidratul Muntaha, and return to Mekkah). Philosophically, it is the symbol of very fast communication, beauty, loyalty, and global. It means that Aceh people should have global thinking and local action. Besides, Buraq means hukom bak Syiah Kuala. Third, crescent and star. Crescent and star is generally called as the symbol of Islam. Islam is the constitution of the state and the way of life of Aceh people. Star means the five pillars of Islam, whereas the crescent is the light of faith. Forth, rencong, shield, and gliwang are the symbol of reusam (tradition) of Aceh state. (reusam is a tool to enforce custom and law, which in this case is done by admiral and sergeant). Rencong is Aceh's unique weapon which is the symbol of defense. Rencong is made with special design from Arabic word: "Bismillah" which means with the name of Allah). Fifth, Rice is the symbol of prosperity. Pade Peunadjoh Phonbansa Aceh (Rice is eaten daily food of Aceh people). Sixth, the symbol of chain (renekrenek) is qanun Neugara Aceh. Seventh, the symbol of anchor is where Aceh Island is anchored, two lines above the anchor symbolize Majelis Tuhapeut Neugara Aceh. Eighth, the text below the symbol of "Hudep Beusare Mate Beusajan" means that Aceh people should be tiger in life, together in death". This symbol also means national loyalty. Ninth, in that symbol there is also the steering wheel which contain the letter $\mathrm{T}$ in the wheel. The letter "T" is symbol of first alphabet of Aceh title for noblemen, namely Tuanku, Tengku and Teuku .It is the symbol of unity of Aceh ruler. Seen from its position, buraq is on the left side and lion is on the right side, which means seen from alphabet perspective, so it should be read lion-buraq, but in fact there is influence from Arabian culture in writing, so the spelling is began from the right not from the left, so it is read buraq-lion, and that symbol is created by The Free Aceh Movement founder, Tengku Hasan di Tiro. The description of symbol in English is done by dr. Husaini Hasan.

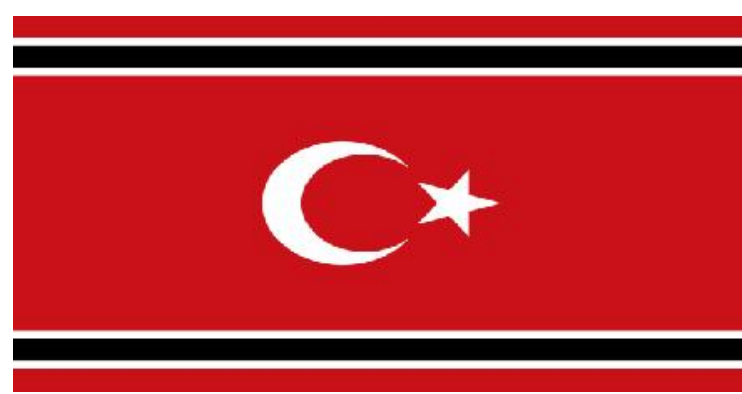

Fig. 4. Aceh free movement flag.

Next, about the flag of GAM, there is philosophical meaning from this flag, namely: First, the black line has meaning that Aceh kingdom is ever vacuum (vacuum in power) and as a sign to remember syuhada. Second, the black line has meaning that war to achieve independence is holy war, and those who died in that war get Pahala Syahid. Third, the 
red background has meaning that Aceh People are obligated to defend and maintain the right and destroy the evil. Forth, the star has meaning representation of five pillars of Islam, whereas the moon or crescent means as the light of faith. As for the general meaning of GAM flag is that Aceh nation are willing to shed a blood to defend the right and destroy the evil. do Islam pillars under the protection of the light of faith (Bansa Atjeh Neutem Meuro Darah Untuk Peudong Njang Hak Dan Peuhantjoe Njang Bateu Neupeudjak Rukon Islam Dimi Jueb Lindungan Tjahaya Iman). The waving of GAM flag often done coincided with Adzan call. With basic assumption, when Rasullulah conquer Mecca city, he ask Bilal bin Rabbah to voice Adzan and in the same time to wave victory flag. It is in accord with one of adzan lafaz, Haiya-Alal-Falah (let's go toward the victory)

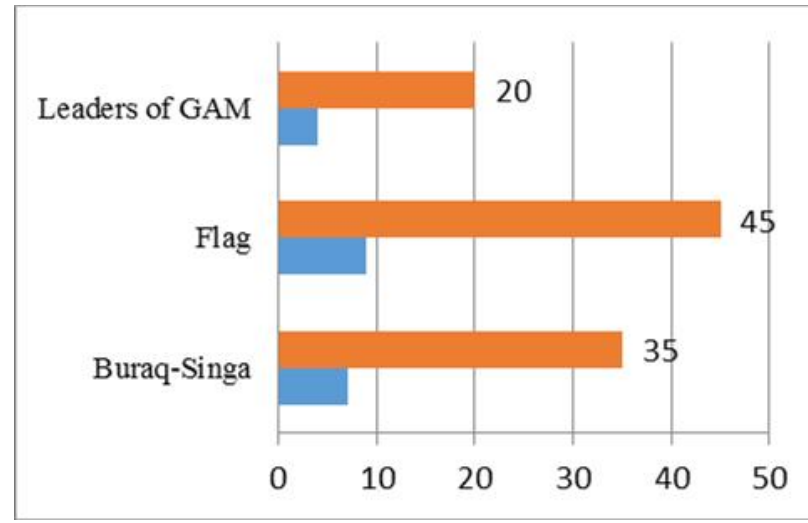

Fig. 5. Social media accounts containing GAM.

This study result is seen from the perspective of semiotics theory delivered by Charles Sanders Peirce say that "For Peirce, sign is something which stands to somebody for something in some respect or capacity" Peirce call something used to make the sign functioned as ground [10]. As consequence, sign always contained in triadic relation, namely ground, object and interpretant. Based on this relation, Peirce make classification for sign. The Signs related to ground are divided into qualisign, sinsign, and legisign. Qualisign is quality contained in sign, in this case related to the signs contained Buraq-lion symbol as the symbol of The Free Aceh Movement or GAM. In the Buraq-lion symbol there are nine signs in it, as explained above. Those nine signs are designed based on custom and tradition in Aceh society, so when they see buraq-lion symbol, the sense of fanatic increase, and raise their patriotic attitude, so when The Free Aceh Movement is declared, it get supported from most people in Aceh, including those with high social status. In the wall of media social observed, there are message about people heroism which is equated with Buraq-Lion symbol, so each Facebook user who see this symbol will feel resentment to Central government, and the growth of attitude to defend GAM symbol which is now recognized as separatism. Next, it is seen from its object, Peirce divide the signs into icon, index, and symbol [10]. Icon is a sign related to signifier and signified which are similar in natural form. Or in the other word, icon is relations between sign and object or reference which have resemblance nature, for example photograph and map. Index is the sign which show the existence of natural relation between sign and signified which has causal-effect relation, or the sign which refer directly to reality. Regarding the flag, the symbol of Free Aceh contained in some formal organizations such as in Aceh local party namely Partai Aceh (PA). In additions has resemblance, those parties and organizations also use the symbol which resemble the separatist symbol. Of course, it will give influence to general people. From the finding result, it is known that the symbol of The Free Aceh Movement which is mostly influencing from socialization through media social is the symbol of flag, as seen in figure 6 above with $45 \%$ users are influenced by the symbol of flag compared with the GAM figures. It is because the philosophy contained in that symbol is in accord with the thinking of people in Aceh. It is in accord with Peirce that symbol as the form of soul representation of community seen from culture perspective [10].

\section{CONCLUSION}

The socialization of The Free Aceh Movement or Gerakan Aceh Merdeka (GAM) symbols through media social is continuously done by groups of GAM who still not accept peace agreement held in Helsinki on $15^{\text {th }}$ August 2005. Now, there are those who stay abroad, who stay in Indonesia but outside Aceh, and there are also those who stay in Aceh. The promotion of GAM symbol is continuously done with the hope that ideology of GAM can exist anymore post peace agreement, because what they want is Aceh as sovereign nation which is equalized with another nations in the world. It is as ever agreed by them when they are joined with GAM organization before peace agreement. If the socialization of GAM symbol is continuously done and the government let it, then GAM ideology gradually will be continuously inherited to new generation, and it will potentially cause the born of the new Free Aceh Movement, which means that the socialization of GAM symbol can become potential and threat to make Aceh return to conflict cycle in the future. Therefore, the strategic steps are needed to strengthened national ideology in Aceh which exceed ethno-nationalism ideology.

\section{REFERENCES}

[1] Maimun, Reintegrasi Aceh dalam Bidang Politik, Ekonomi dan Sosial. Tesis; Universiti Kebangsaan Malaysia, 2010.

[2] A.H. Hamid, Potensi konflik dalam proses reintegrasi Aceh. Makalah yang disajikan dalam diskusi publik-peluncuran buku\& website "mengawal demokrasi, membagun Aceh baru: 14 november 2008.

[3] M. Nurhasim, Konflik dan integrasi politik Gerakan Aceh Merdeka: kajian tentang consensus normative antara RI-GAM dalam perundingan Helsinki. Jakarta: P2P-LIPI dan Pustaka Pelajar, 2008.

[4] Y. Rusli, Pendidikan Karakter Kebangsaan (Seri Praktis Pembangunan Karakter di Perguruan Tinggi dalam Upaya mewujdukan Pemerintahan Yang Baik). Banda Aceh: Bina Karya Akademika, 2017.

[5] E. Aspinal, Sejarah konflik Aceh. Jakarta: Raja Grafindo Persada, 2008.

[6] J. Galtung, "Cultural Violence,” Journal of Peace Research, pp. 291-305, 1990.

[7] Van Het Hof, SecilDeren. "emblems as Symbolsof political party ideologi,” SEMIO Journal, vol. 3, 2017.

[8] I.J. Piliang, Bouraq-Singa Kontra Garuda: Pengaruh Sistem Lambang Dalam Separatisme GAM. Jakarta; Penerbit Ombak, 2010. 
[9] Wahju Wibowo, Indiwan Seto. Semiotika; Aplikasi Praktis Bagi Penelitian dan Penulisan Skripsi Ilmu Komunikasi. Jakarta: Penerbit Mitra Wacana Media, 2009.
[10] J. JakóbLiszka, A General Introduction to the Semeiotic of Charles Sanders Peirce. Indiana University Press Bloomington And Indianapolis, 1996.

[11] L.J. Moleong, Metodologi Penelitian Kualitatif. PT. Remaja Rosdakarya, Bandung, 2016. 